\title{
PROTECTING THE UNION RULE OF LAW THROUGH NATIONAL COURT SCRUTINY? A COMMENT ON JOINED CASES C-354/20 PPU AND C-412/20 PPU L AND P
}

\author{
AGNES BAUDE*
}

This contribution is a comment on the ECJ's judgment of $20^{\text {th }}$ December 2020 in L and P, which is a follow-up on the Court's earlier ruling in LM - Minister for Justice and Equality (Deficiencies in the system of justice). It covers the key findings of the Advocate General's Opinion, the judgment of the Court of Justice and the following implications for the national courts within the Judicial cooperation in criminal matters. The analysis investigates the case-law from a constitutional as well as a national perspective, with its main focus on pivotal considerations for the national courts within the execution of a European Arrest Warrant issued by a Rule of Law-backsliding country. The theoretical horizontal dialogue established by the Court is scrutinised in an attempt to concretise the diverse steps of the national examination of the judiciary in the issuing Member State.

\section{INTRODUCTION}

On $20^{\text {th }}$ December 2020 in the $L$ and $P^{1}$ case the Court of Justice of the EU (CJEU, ECJ, the Court) continued its earlier case-law stemming from the $L M^{2}$ case and the landmark ruling in Aranyosi and Căldăraru ${ }^{3}$. The issue of fact concerns European extradition through the Framework Decision of a European Arrest Warrant ${ }^{4}$ (FD EAW) but raises broader questions vis-à-vis Member State compliance with fundamental rights and the rule of law. Notably, the balance between the cornerstone principles of effectiveness ${ }^{5}$ of the EU area of freedom, security and justice (AFSJ) ${ }^{6}$, i.e. the principle of mutual trust and the principle of mutual recognition ${ }^{7}$ vs. the common values of the EU in Article 2 TEU plays a central role in the Court's reasoning.

The rule of law backsliding in some EU Member States, especially Poland and Hungary, through deficiencies in the judiciary has led to a crisis impacting several dimensions of the European cooperation. ${ }^{8}$ Respect for the rule of law is of fundamental importance in

\footnotetext{
* Mannheimer Swartling.

1 Joined Cases C-354/20 and C-412/20 L and P EU:C:2020:1033.

2 Case C-216/18 PPU LM - Minister for Justice and Equality (Deficiencies in the system of justice) EU:C:2018:586.

3 Joined Cases C-404/15 and C-659/15 PPU Aranyosi and Căldăraru EU:C:2016:198.

${ }^{4}$ Council Framework Decision 2002/584/JHA of 13 June 2002 on the European arrest warrant and the surrender procedures between Member States (OJ 2002 L 190, p. 1), as amended by Council Framework Decision 2009/299/JHA of 26 February 2009 (OJ 2009 L 81, p. 24).

5 The principle of mutual recognition was established within the internal market concerning free movement of goods in the landmark ruling in Case C-120/78 Cassis de Dijon EU:C:1979:42.

${ }^{6}$ Article 3.2 TEU.

${ }^{7}$ See e.g. Recital 6 of Council Framework Decision 2002/584/JHA of 13 June 2002 on the European arrest warrant and the surrender procedures between Member States; Case C-216/18 PPU LM EU:C:2018:586, para 41; Joined Cases C-354/20 and C-412/20 L and P EU:C:2020:1033, para 36.

8 Theodore Konstadinides, The Rule of Law in the European Union: The Internal Dimension (Hart Publishing, 2017), IX.
} 
the Union ${ }^{9}$ and thus a pre-condition for accession to the EU according to Article 49 TEU. Pursuant to Article 2 TEU, the rule of law is a common value between the Member States. ${ }^{10}$ In a situation when a Member State no longer observe the EU common values, Article 7 TEU - "the nuclear option" ", provides a political mechanism by which the concerned Member State might lose authorities within the Union. ${ }^{12}$ The mechanism is political since the decision making lies within the authority of the Council. Furthermore, the decision requires unanimity, which in practice rules out the implementation of the mechanism in a situation where there are more than one Member State that disrespects the fundamental values of the EU. In 2017, the European Commission (Commission) launched a reasoned proposal in accordance with Article 7(1) for a Council decision on the determination of a clear risk of a serious breach by Poland of the rule of law. ${ }^{13}$ In September 2018, the Parliament launched a proposal against Hungary. ${ }^{14}$ Today, more than three years later, the negotiations are still pending in the Council.

The European judicial cooperation in criminal matters, which is founded on the principles of mutual trust and mutual recognition ${ }^{15}$, is one dimension that is perceptibly affected by the dismantling of the judiciary's independence. The principle of mutual recognition introduced free movement for judgments and decisions in criminal matters, primarily on grounds of effectiveness in the fight against organised crime and terrorism in the EU. ${ }^{16}$ The cooperation in criminal matters presupposes autonomous and functioning national courts that are able to ensure the fundamental rights of individuals ${ }^{17}$, e.g. the right to an effective remedy and a fair trial in Article 47 of the EU Charter. The FD EAW, launched in June 2002, was the first mechanism applying the principle of mutual recognition in the European judicial cooperation in criminal matters, and likely still the most substantial result of the judicial cooperation. ${ }^{18}$ As an immediate response on the $9 / 11$ attacks the

\footnotetext{
9 The founding character of the rule of law within the Union was established for the first time in Case 294/83 Les Verts v. Parliament EU:C:1986:166.

${ }^{10}$ Article 2 TEU states "The Union is founded on the values of respect for human dignity, freedom, democracy, equality, the rule of law and respect for human rights, including the rights of persons belonging to minorities. These values are common to the Member States in a society in which pluralism, nondiscrimination, tolerance, justice, solidarity and equality between women and men prevail". 11 SPEECH/13/684, Barroso "State of the Union address 2013" (11 September 2013).

<http://europa.eu/rapid/press-release_SPEECH-13-684_en.htm> accessed 19 May 2021.

12 Article 7(3) TEU.

${ }^{13}$ European Commission, Reasoned proposal in accordance with Article 7.1 of the Treaty on European Union regarding the rule of law in Poland: Proposal for a Council decision on the determination of a clear risk of a serious breach by the Republic of Poland of the rule of law, $\operatorname{COM(2017)~} 835$ final.

${ }_{14}$ Proposal for a Council decision on the determination of a clear risk of a serious breach by the Republic of Hungary of the rule of law, 2018/0902(NLE).

${ }^{15}$ Case C-216/18 PPU LM EU:C:2018:586, para 41; Joined Cases C-354/20 and C-412/20 L and P EU:C:2020:1033, para 36.

16 Theodore Konstadinides 'The Europeanisation of extradition: how many light years away to mutual confidence?', in Christine Eckes (eds), Crime within the Area of Freedom, Security and Justice (Cambridge University Press, 2011) 192-223, 192; Ester Herlin-Karnell 'Ett konstitutionellt perspektiv på frågan om tillit inom EU:s straffrättsliga samarbete' in Antonina Bakardjieva Engelbrekt et al (eds.) Tilliten i EU i ett vägskäl (Santérus förlag, 2017) 161-184, 163.

${ }^{17}$ Case C-452/16 PPU Poltorak EU:C:2016:858, paras 44-45; Koen Lenaerts 'La vie après l'Avis: Exploring the principle of mutual (yet not blind) trust', Common Market Law Review, Vol. 54 (2017) 805-840, 810-813. ${ }^{18}$ European Commission, Report from the Commission based on Article 34 of the Council Framework Decision of 13 June 2002 on the European arrest warrant and the surrender procedures between Member States, COM(2005) 63 final, 2; Libor Klimek European Arrest Warrant (Springer International Publishing, 2015), 32 .
} 
Commission introduced a new system for European extradition replacing the traditional system with a faster and more effective procedure through e.g. limited grounds for nonexecution. ${ }^{19}$ The FD EAW is well-established in the Union, a "success" 20 according to the Commission, but still controversial ${ }^{21}$ and has raised multiple questions in the context of preliminary ruling procedures. ${ }^{22}$

ECJ's most recent ruling in the area, $L$ and $P$, does not in substance differ from its earlier case-law in $L M$ and the two-step test concerning a horizontal rule of law scrutiny of the issuing authority of an EAW. Nevertheless, $L$ and $P$ is of interest because of the Court's explicit confirmation of the executing authority's responsibility to thoroughly perform each step of the complex examination of the independence of its European counterpart. The following case-note starts off by giving a background to the $L$ and $P$ case, including the facts of the case. The third section consists of the Opinion of the Advocate General, followed by the key findings in the Court's judgment in section four. Section five covers an analysis of $L$ and $P$ from two perspectives: a general constitutional perspective, and a national perspective. Within the analysis of the national perspective, the judgment's concrete implications for the national courts is discussed. The case-note ends with concluding remarks concerning e.g. the suitability of the chosen method of the Court.

\section{BACKGROUND TO THE CASE}

\subsection{GENERAL BACKGROUND}

The present weakening of the judiciary's independence, particularly in Poland, has been subject for numerous infringement procedures from the Commission as well as multiple preliminary ruling procedures from both national courts in Poland and courts of other Member States, the latter notably in the area of the AFSJ. ${ }^{23}$ In a situation where the political alternatives, such as the Article 7-procedure and the Commission's different soft law frameworks ${ }^{24}$, reveals to be insufficient, the ECJ has stepped up to protect the independence of the European courts and judges. ${ }^{25}$ The judicial independence within the EU rule of law has via the case-law of the Court of Justice gradually evolved to a constitutional principle in

\footnotetext{
${ }^{19}$ Libor Klimek Mutual Recognition of Judicial Decisions in European Criminal Law (Springer International Publishing, 2017), 142; Theodore Konstadinides 'The Europeanisation of extradition: how many light years away to mutual confidence?' (n 16) 197.

${ }^{20}$ European Commission, Report from the Commission on the implementation since 2005 of the Council Framework Decision of 13 June 2002 on the European arrest warrant and the surrender procedures between Member States, COM(2007) 407 final, 2.

${ }^{21}$ Theodore Konstadinides, 'Judicial independence and the Rule of Law in the context of non-execution of European Arrest Warrant: LM', Common Market Law Review, Vol. 56 (2019) 743-770, 744.

${ }^{22}$ See for example Case C-396/11 Radu EU:C:2013:39; Case C-399/11 Melloni EU:C:2013:107; Case C452/16 PPU Poltorak EU:C:2016:858; Case C-128/18 Dorobantu EU:C:2019:857.

${ }^{23}$ Joined Cases C-404/15 and C-659/15 PPU Aranyosi and Căldăraru EU:C:2016:198.

${ }^{24}$ See e.g. European Commission, Communication from the Commission to the European Parliament, the Council, the European Economic and Social Committee and the Committee of the Regions on 2020 Rule of Law Report, COM(2020) 580 final; European Commission, Communication from the Commission to the European Parliament and the Council on A new EU Framework to strengthen the Rule of Law, COM(2014) 158 final. annual Rule of law report (2020), rule of law framework (2014) etc.

${ }^{25}$ Laurent Pech and Dimitry Kochenov 'Respect for the Rule of Law of the European Court of Justice: A Casebook Overview of Key Judgments since the Portugese Judges Case', SIEPS Report (Stockholm, 2021), 2-3.
} 
the Union which is enforceable through a combined reading of Article 19(1) TEU and Articles 2 and 4(3) TEU. ${ }^{26}$ Sub-components of the principle of judicial independence has been substantialised via Article 47 of the Charter, comprising inter alia the principle of irremovability of judges. ${ }^{27}$

In a preliminary ruling requested from an Irish court in 2018 ( $L M$ - Minister for Justice and Equality ${ }^{28}$ ), the ECJ established a horizontal dialogue between the Member States concerning the independence of the issuing judicial authority of an EAW. The $L M$ case confirmed a two-step test that initially had been adopted in the Aranyosi and Căldăraru case in the context of systematic deficiencies affecting the conditions in prisons, which were potentially detrimental to the dignity of the person of surrender pursuant to an EAW. ${ }^{29}$ In essence, the $L M$ test shall be carried out by an executing judicial authority within the execution of an EAW issued from a rule of law backsliding country. The test entails an assessment of the deficiencies in the judiciary as a whole, alongside a scrutiny of the independence of the specific issuing judicial authority of the EAW and the potential implications in the concrete case at hand. To summarise, the test requires: (1) systematic or generalised deficiencies affecting the independence of judicial bodies in the issuing Member State, and (2) evidence of a real risk that the requested person's fundamental rights will be breached in the context of surrender by an $\mathrm{EAW}^{30}$, i.e. a risk of suffering a breach of the rights to a fair trial pursuant to Article 47 of the Charter. The steps in the two-pronged rule of law test are cumulative and cannot be confused or assessed in general terms. ${ }^{31}$ If both the general test and the individual test are met, the executing country shall refuse to extradite the requested person. ${ }^{32}$ In order to fulfill the $L M$ test the executing judicial authority shall use the mechanism for additional information provided in the FD EAW ${ }^{33}$, thus initiating a wideranging horizontal dialogue between the executing and issuing authorities.

In the so-called Prosecutors' Cases ${ }^{34}$ the ECJ established the notion of a 'judicial authority' within the FD EAW as "an autonomous concept of EU law"35. The criteria revolve around the independence of the authority and the possibilities of political interference in its decisionmaking, not only in the specific case, but in general. ${ }^{36}$ The mere formal possibility in law, even if never used in practice, to receive instructions from the executive in the exercise of its

\footnotetext{
${ }^{26}$ Case C-64/16 Associação Sindical dos Juizes Portugueses (ASJP) EU:C:2018:117, was the first landmark ruling in the materialization of the Union rule of law; see also Pech and Kochenov (n 25).

27 Pech and Kochenov (n 25) 9-10.

${ }^{28}$ Case C-216/18 PPU LM EU:C:2018:586.

29 Joined Cases C-404/15 and C-659/15 PPU Aranyosi and Căldăraru EU:C:2016:198, paras 85-90.

30 Opinion of Advocate General Campos Sánchez-Bordona in Joined Cases C-354/20 PPU and C-412/20 PPU L and P EU:C:2020:295, para 1.

31 Joined Cases C-354/20 and C-412/20 L and P EU:C:2020:1033, para 55-56.

32 Case C-216/18 PPU LM EU:C:2018:586, para 78.

33 Article 15(2) of Council Framework Decision 2002/584/JHA of 13 June 2002 on the European arrest warrant and the surrender procedures between Member States.

${ }^{34}$ Case C-452/16 PPU Poltorak EU:C:2016:858; Case C-453/16 PPU Özrelik EU:C:2016:860; Case C-477/16 PPU Kovalkovas EU:C:2016:861; Joined Cases C-508/18 and C-82/19 PPU OG and PI EU:C:2019:456; Case C-509/18 PF EU:C:2019:457; Joined Cases C-566/19 PPU and C-626/19 PPU JR and YC EU:C:2019:1077; Case C-625/19 PPU XD EU:C:2019:1078; Case C-627/19 PPU ZB 2019:1079; Case C-510/19 AZ EU:C:2020:953; C-584/19 Staatsanwaltschaft EU:C:2020:1002.

35 Case C-477/16 PPU Kovalkovas EU:C:2016:861, para 48.

${ }^{36}$ Joined Cases C-508/18 and C-82/19 PPU OG and PI EU:C:2019:456, paras 78-80.
} 
functions precludes status as a 'judicial authority' within the FD EAW. ${ }^{37}$ The Prosecutors' cases has thus established a considerably more strict requirement of the judicial authority's independence than the two-pronged test stated in $L M .^{38}$

\subsection{FACTS OF THE CASE}

The ECJ ruling in joined cases $L$ and $P$ originate in the deteriorating rule of law situation in Poland subsequent the $L M$ ruling. In particular, the worsening of the situation regard the recent extensive reforms of the judiciary which became effective in February 2020 (the "muzzle law"39) and the outcome of several preliminary rulings referenced by Polish courts, such as $A K$ and Others (Independence of Disciplinary Chamber) ${ }^{40}$ and Miasto Lowicz and Prokurator Generalny ${ }^{41}$. The reference for a preliminary ruling in $L$ and $P$ came from a Dutch court, Rechtbank Amsterdam, which is the sole executing judicial authority in the Netherlands. The national cases concern the surrender of two Polish citizens pursuant to EAWs issued by Polish courts. In L, the person was requested for criminal prosecution..$^{42}$ In $\mathrm{P}$, the person was requested to be surrendered for execution of a custodial verdict, sentenced in July 2019. ${ }^{43}$

The questions for reference were submitted in July and September 2020 and primarily drew upon two alternative lines. The first line relates to the Prosecutors' Cases and the possible application of the Court's case-law when examining a court as the issuing judicial authority. The alternative line concerns the executing authority's obligation to ascertain risks in the individual case; the Dutch court argued that it is apparent from the recent developments in Poland that the systemic and generalised deficiencies concerning the independence of the Polish judiciary, with the result that the right to an independent tribunal is no longer guaranteed for any person obliged to appear before a Polish court, results in the second step being unnecessary. ${ }^{44}$ In other words, as put by the Advocate General, the national court asks if "it is entitled to refuse the surrender requested by a Polish court without the need to examine in detail the specific circumstances pertaining to the EAW" ${ }^{45}$. Within the reference

\footnotetext{
${ }^{37}$ Joined Cases C-508/18 and C-82/19 PPU OG and PI EU:C:2019:456, 88; Martin Böse 'The European arrest warrant and the independence of public prosecutors: $O G \& P I, P F, J F \& Y C$, Common Market Law Review, No. 57 (2020) 1259-1282, 1279.

${ }^{38}$ Laurent Pech and Dimitry Kochenov 'Respect for the Rule of Law of the European Court of Justice: A Casebook Overview of Key Judgments since the Portugese Judges Case', SIEPS Report (Stockholm, 2021), 117.

39 The so-called muzzle law has led to multiple controversies both internal and external, i.e. from EU-horizon as well as from the Venice commission and other international organisations. See e.g. Laurent Pech, Sadurski Wojciech and Kim Lane Scheppele 'Open Letter to the President of the European Commission regarding Poland's "Muzzle Law"” (V erfblog 9 March 2020) < https:/ / verfassungsblog.de/open-letter-to-the-president-ofthe-european-commission-regarding-polands-muzzle-law/> accessed 19 May 2021; Themis newsletter 'Close to the point of no return (newsletter about the situation of the Polish judiciary)' (20 February 2020) <http://themis-sedziowie.eu/wp-content/uploads/2020/02/Newsletter.pdf> accessed 19 May 2021; Euronews 'Hundreds of judges and lawyers protest against Polish 'muzzle-law' (11 January 2020) <https://www.euronews.com/2020/01/11/hundreds-of-judges-and-lawyers-join-warsaw-protest-againstpolish-muzzle-law> accessed 19 May 2021; Freedom House 'Poland: Restrictive Judiciary Law Sets Dangerous Precedent' (23 January 2020) <https://freedomhouse.org/article/poland-restrictive-judiciary-law-setsdangerous-precedent $>$ accessed 19 May 2021.

${ }^{40}$ Joined Cases C-585/18, C-624/18 and C-625/18 AK and Others EU:C:2019:982.

${ }^{41}$ Joined Cases C-558/18 and C-563/18 Miasto Lowicz and Prokurator Generalny EU:C:2020:234.

42 Request for a preliminary ruling in Case C-354/20 PPU.

${ }^{43}$ Joined Cases C-354/20 and C-412/20 L and P EU:C:2020:1033, para 23.

${ }^{44}$ Joined Cases C-354/20 and C-412/20 L and P EU:C:2020:1033, paras 14-19.

45 Opinion of Advocate General Campos Sánchez-Bordona in Joined Cases C-354/20 PPU and C-412/20

PPU L and P EU:C:2020:295, para 5.
} 
of the posterior case $(P)$, Rechtbank Amsterdam added questions regarding the relevant time for the examination of the independence of the courts in the issuing country. ${ }^{46}$

\section{ADVOCATE GENERAL CAMPOS SÁNCHEZ-BORDONA'S OPINION}

The Opinion of Advocate General (hereinafter AG) Campos Sánchez-Bordona focuses on the second question from the referring court, namely, if the recent Polish legislative reforms concerning the independence of the judiciary in themselves can constitute a sufficient ground to refuse to execute an EAW due to the overall risk that a person's right to a fair trial before an independent and impartial tribunal, guaranteed by Article 47 of the Charter, may be breached. ${ }^{47}$ The AG commenced with declaring that the issue of matter in $L$ and $P$ refers to Article 1(3) of the FD EAW relating to the obligation of the Member States to respect fundamental rights, applicable in the $L M$ and Aranyosi and Căldăraru cases. ${ }^{48}$ In the view of the AG, the questions concerning the possibility of refusal to execute an EAW on account of systemic or generalised deficiencies affecting the independence of the judiciary in the issuing Member State "are most important from a general point of view" 49 .

The Opinion of the AG follows the $L M$ caselaw in a strict sense and stresses that the exception earlier laid down by the Court is in itself an "exceptional response" in the context of the FD EAW, a framework which does not lay down any grounds for non-execution in such circumstance. However, when circumstances of such "exceptional nature" concerning generalised or systematic deficiencies of the judiciary's independence exist, the "EU law responds $[. .$.$] in terms which are also exceptional". { }^{0}$ The "exceptional response" of the Union law is, however, limited and does not "go so far as to require the automatic non-execution of every EAW issued by the judicial authority of Member State affected by systematic or generalised deficiencies". ${ }^{51}$ When systematic or generalised deficiencies has been established through "objective, reliable, specific and properly updated evidence" 52 , and after finding "that those deficiencies entail a real risk of infringement of the right to fair trial" executing judicial authority must " as a second step, asses specifically and precisely whether, in the particular circumstances of the case, there are substantial grounds for believing that, following his surrender to the issuing Member State, the requested person will run that risk" 54 . The AG underlined that "no matter how thought-provoking the solution by the referring court may be", the solution is neither compatible with the Court's earlier caselaw nor the FD EAW stating that the EAW mechanism may only be suspended when a determination by the Council pursuant to Article 7(2) and (3) has been laid down. "[A] global solution" where all EAW issued from a from a rule of law backsliding country is thus

\footnotetext{
46 Joined Cases C-354/20 and C-412/20 L and P EU:C:2020:1033, para 25.

47 Opinion of Advocate General Campos Sánchez-Bordona in Joined Cases C-354/20 PPU and C-412/20

PPU L and P EU:C:2020:295, para 29.

48 ibid, para 27.

49 ibid, para 35.

50 ibid, para 44.

51 ibid, para 45.

52 ibid, para 42.

53 ibid, para 46.

54 ibid.

55 ibid, paras 50 and 54-56.
} 
"reserved for when the [Council] formally determines that an issuing Member State has breached the values referred to in Article 2 TEU" ${ }^{\prime 5}$. The AG did indeed agree with the referring court that the "situation obtaining at the time when judgment was given in $[L M]$ was concerning, the subsequent data appear to point to the worsening of that situation" 57 and that the legislative reforms mentioned in the order for reference as well as the ECJ's most recent judgments "make clear that the systematic or generalised deficiencies discernible in relation to the independence of courts in [Poland] are liable to threaten the fundamental rights of persons coming under their jurisdiction" ${ }^{58}$. Nevertheless, according to the AG, the key question is not whether the threat to the independence of Polish courts have worsened or not, but instead "the nature of the body with responsibility for making that finding and acting on it" application of the [FD EAW] in respect of [all EAWs] issued by those courts" ${ }^{60}{ }^{61}$

The view firmly expressed by the AG is that "once systemic or generalised deficiencies have been confirmed in the issuing Member State" ${ }^{\prime 2}$ the executing judicial authority is entitled to refuse surrender of the requested person only "if, having regard to that person's personal situation, the nature of the offence for which he is being prosecuted and the factual context that forms the basis of the EAW, it concludes that that person may actually suffer a breach of the fundamental right he is guaranteed by Article 47 of the Charter" ${ }^{\prime 3}$. As such, the possibility to refuse an EAW "requires a rigorous examination", divided into two steps, to be carried out by the executing country. "In the light of increased systemic or generalised deficiencies, and in the absence of a formal determination by the [Council], [the executing authority] must, therefore, be even more rigorous in its examination of the circumstances pertaining to the EAW which it has been requested to execute, but it is not exempt from the duty to carry out that examination in particular" ${ }^{65}$. The AG further clarified that the information requested by the issuing judicial authority within the subsequent horizontal dialogue under Article 15(2) of the FD EAW "does not only have to be information which is necessary for the purposes of conducting that particular examination but must also be limited to information which the issuing authority is reasonably in a position to provide" ${ }^{\text {. }}$.

The rationale behind the AG's reasoning appears to be that the systematic or generalised deficiencies which can be identified of Polish courts in the first step of the examination does not "deprive those courts of their nature as courts" ${ }^{67}$. In the perspective

\footnotetext{
56 ibid, para 55.

57 ibid, para 57, referring to the Commission Staff Working Document, 2020 Rule of Law Report, Country Chapter on the rule of law situation in Poland (SWD(2020) 320 final): "In its report of September 2020 on the situation regarding the rule of law in the EU, the Commission notes that, in Poland, 'the reforms, impacting the Constitutional Tribunal, the Supreme Court, ordinary courts, the National Council for the Judiciary and the prosecution service, have increased the influence of the executive and legislative powers over the justice system and therefore weakened judicial independence"'.

58 Opinion of Advocate General Campos Sánchez-Bordona delivered in Joined Cases C-354/20 PPU and C412/20 PPU L and P EU:C:2020:295, para 58.

59 ibid, para 61.

60 ibid, para 60.

61 ibid, paras 59-61.

62 ibid, para 62.

${ }^{63}$ ibid.

${ }^{64} \mathrm{ibid}$, para 47.

65 ibid, para 76, italics added.

66 ibid, para 77.

67 ibid, para 72 .
} 
of the AG, the Polish courts continue to be courts within the meaning of EU law, "even though the independence of the judiciary, taken to mean a group of courts which exercise jurisdiction, is threatened by governmental structures (or, also, by the anomalous performance of disciplinary functions) ${ }^{\prime 68}$.

Concerning the relevant time for the assessment whether the authority is an independent judicial body, the AG "believe[s] that it is irrelevant" ${ }^{69}$ whether the systematic or generalised deficiencies had worsened before or after an EAW was issued. ${ }^{70}$ The principal consideration for the executing judicial authority is whether the issuing judicial body, which has "to rule on the requested person's fate following his surrender"," "retains its independence to give judgment on that person's situation free from external interference, threats or pressure" 72 . The AG stresses the importance for the executing judicial authority to "liaise with a judicial interlocutor in the issuing Member State" "), and given the EAW procedure's impact on liberty it may be "necessary to gather additional information which will enable the executing authority to establish exactly the facts which form the basis of the EAW $[\ldots]$ and, in particular, what circumstances the requested person will find himself in following his surrender" ${ }^{74}$. In other words, when the executing authority is faced with a situation of increasing systematic and generalised deficiencies in the judiciary of the issuing country, the executing judicial authority may be obliged to not only interfere with the issuing judicial authority in the context of the rule of law-examination, but to also seek objective information concerning the independence of that issuing authority and the individual situation for the requested person.

\section{FINDINGS OF THE COURT}

In substance, the judgment of the Court (Grand Chamber) upholds the same position as the Opinion from the Advocate General. The reasoning, particularly concerning the first question from the referring court, does however differ from the Opinion. The Court also elaborated on the relevant time for the assessment of the issuing judicial authority's independence.

\subsection{CASE-LAW ON 'ISSUING JUDICIAL AUTHORITY’ NOT APPLICABLE}

The Court first dealt with the primary question from the referring court: if the case-law regarding the notion of "judicial authority" in the context of the FD EAW is applicable in the situations at hand. ${ }^{75}$ ECJ started to highlight that both the fundamental principles of mutual trust and mutual recognition requires, "save in exceptional circumstances" 76 , all Member States to consider that their Union counterparts comply "with EU law and

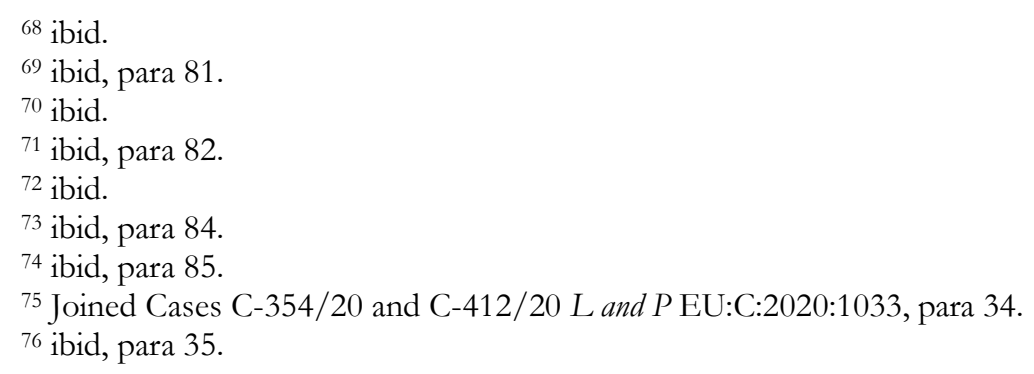


particularly with the fundamental rights recognised by EU law" "77. All Member States are, pursuant to the principle of mutual recognition explicitly stated in Article 1(2) of the FD EAW, required to execute an EAW issued by another Member State. Following the FD EAW and the exhaustively listed grounds for non-execution, execution of an EAW constitutes the rule, and refusal to execute is an exception which must be interpreted strictly. ${ }^{78}$ However, the above stated only applies to 'judicial decisions' issued by a 'judicial authority' within the meaning of Article 6(1) of the FD EAW, which implies that "the authority concerned acts independently in the execution of those of its responsibilities which are inherent in the issuing of [an EAW]" " In that regard, the Court recalled that "the requirement of judicial independence forms part of the essence of the fundamental right to a fair trial, a right which is of cardinal importance as a guarantee that all the rights which individuals derive from EU law will be protected and that the values common to the Member States, set out in Article 2, in particular the rule of law, will be safeguarded" 80 .

Nonetheless, the Court found that an executing judicial authority cannot "deny the status of 'issuing judicial authority', within the meaning of the [EAW], to all judges and courts [...], acting by their nature entirely independently of the executive" ${ }^{81}$, in a rule of law backsliding Member State. Such interpretation, encouraged by the referring court, would "amount to extending the limitations that may be placed on the principles of mutual trust and mutual recognition beyond 'exceptional circumstances' by leading to a general exclusion of the application of those principles in the context of [EAWs] issued by the courts of the Member State concerned by [...] deficiencies". ${ }^{82}$ In the view of the ECJ, this would accordingly result in that "no court of that Member State could any longer be regarded as a 'court or tribunal' for the purposes of the application of other provisions of EU law, in particular Article 267 TFEU" 83.

The Court consequently ruled out the applicability of the case-law from the Prosecutors' Cases with reference to the substantive differences between those cases and the situations at hand in $L$ and $P$, as well as the situation in $L M .^{84}$ In the context, the Court drew attention to its previous findings in OG and PI (Lübeck and Zwickau Public Prosecutor's Offices), in which it stated that the notion of 'judicial authority' "are not limited to designating only the judges or courts of a Member State, but must be construed as designating, more broadly, the authorities participating in the administration of criminal justice in that Member State, as distinct from, inter alia, ministries or police services which are part of the executive" 85 . The Court thereafter ascertained that "[i]n European Union law, the requirement that courts be independent

\footnotetext{
$77 \mathrm{ibid}$, referring to e.g. Opinion 2/13 of the Court, EU:C:2014:2454, which raised the principles of mutual trust and mutual recognition to the status as fundamental principles in EU law, thus establishing a strict approach of effectiveness - See Eduardo Gill-Pedro and Xavier Groussot 'The Duty of Mutual Trust in EU Law and the Duty to Secure Human Rights: Can the EU's Accession to the ECHR Ease the Tension?', Nordic Journal of Human Rights, 35:3 (2017), 258-274.

${ }_{78}$ Joined Cases C-354/20 and C-412/20 L and P EU:C:2020:1033, para 37.

79 ibid, para 38, referring to e.g. Joined Cases C-508/18 and C-82/19 PPU OG and PI EU:C:2019:456.

80 Joined Cases C-354/20 and C-412/20 L and P EU:C:2020:1033, para 39.

81 ibid, para 42.

82 ibid, para 43.

83 ibid, para 44.

84 ibid, paras 45-50; i.e. the difference between 'prosecutors' and 'courts' within the law enforcement service.

85 ibid, para 46, italics added, referring to Joined Cases C-508/18 and C-82/19 PPU OG and PI

EU:C:2019:456, para 50.
} 
precludes the possibility that they may be subject to a hierarchical constraint or subordinated to any other body and that they may take orders or instructions from any source whatsoever" ${ }^{\prime 86}$. Given the reasoning of the Court, the more stringent independence-test construed in the Prosecutors' Cases concerning 'judicial authority' is thus precluded in situations when a court has issued the EAW.

\subsection{NO SHORTCUT IN THE TWO-STEP TEST}

After dealing with the notion of 'judicial authority' within Article 6(1) of the FD EAW, the Court turned to the second question of the referring court, namely if the executing judicial authority, on account of systematic or generalised deficiencies concerning the independence of the judiciary of the issuing Member state, may presume (i.e. without carrying out a specific and precise assessment of the person's individual situation) that he or she will run a real risk of breach of his or her fundamental right to a fair trial guaranteed by Article 47(2) of the Charter. $^{87}$

The Court, similar to the AG, maintains its earlier case-law and leaves no room for a simplification of the two-step test established in $L M$ concerning the possibility of refusing to execute an EAW pursuant to Article 1(3) of the FD EAW. ${ }^{88}$ The Court stressed that the two steps of the assessment involve "an analysis of the information obtained on the basis of different criteria, with the result that those steps cannot overlap with one another" ${ }^{89}$. In the context of the first step, the executing judicial authority must "determine whether there is objective, reliable, specific and properly updated material indicating that there is a real risk of breach of the fundamental right to a fair trial [...] on account of systemic or generalised deficiencies so far as concerns the independence of the issuing Member State's judiciary" ${ }^{90}$. Within the second step, the executing authority must first determine "specifically and precisely, to what extent those deficiencies are liable to have an impact at the level of the courts of that Member State which have jurisdiction over the proceedings to which the requested person will be subject" ${ }^{\prime 1}$. Next, the executing authority must determine whether "having regard to his or her personal situation, to the nature of the offence for which he or she is being prosecuted and the factual context in which that arrest warrant was issued, and in the light of any information provided by that Member State pursuant to Article 15(2) of the [FD EAW], there are substantial grounds for believing that that person will run such a risk if he or she is surrendered to that Member State"92.

In line with the Opinion of the AG, the Court also underlined that the implementation of the FD EAW may be suspended only "in the event of a serious and persistent breach by one of the Member States of the principles set out in Article 2 TEU, including that of the rule of law, determined by the European Council pursuant to Article 7(2) TEU, with the consequences set out in Article 7(3) TEU'93. Until such decision has been adopted, no

\footnotetext{
${ }^{86}$ Joined Cases C-354/20 and C-412/20 L and P EU:C:2020:1033, para 49.

87 ibid, para 51.

88 ibid, paras 52-64.

89 ibid, para 56.

90 ibid, para 54 .

91 ibid, para 55.

92 ibid.

93 ibid, para 57.
} 
automatic refusal to execute an EAW, and thus a "de facto suspension of the [EAW] mechanism"94, from a rule of law backsliding Member State is possible. ${ }^{95}$ This also applies in a situation when there are indications of increased systemic or generalised deficiencies concerning the independence of the judiciary of the issuing Member State. In the event of further deterioration of the respect for the rule of law in the issuing court, the Court found that the executing authority must "exercise vigilance" in its examination of the issuing authority, but "it cannot, however, rely on that finding alone in order to refrain from carrying out the second step of the examination" 97 . In this context, the Court also highlighted the objective of the mechanism of the EAW that "is in particular to combat the impunity of a requested person who is present in territory other than that in which he or she has allegedly committed an offence" ${ }^{98}$, which also precludes an interpretation of Article 1(3) of the FD EAW that opens up for refusal to execute an EAW on solely presumptions of the risk of a breach of the fundamental right to a fair trial. ${ }^{99}$

\subsection{RELEVANT TIME FOR THE EXAMINATION}

Concerning the question whether the executing judicial authority should take account of systemic or generalised deficiencies regarding the independence of the courts in the issuing country which have occurred after the issue of an EAW, the Court started by recalling that an arrest warrant may be issued "both for the purposes of conducting a criminal prosecution and for the purposes of executing a custodial sentence or detention order" ${ }^{100}$. On account of the purpose of the EAW, the relevant time for when the deficiencies in the judiciary emerged differ.

In a situation when an EAW is issued for the purposes of conducting a criminal prosecution, such as in the main proceedings in $L$, the executing judicial authority must, "in order to assess specifically and precisely whether in the particular circumstances of the case there are substantial grounds for believing that following that surrender that person will run a real risk of breach of his or her fundamental right to a fair trial, examine in particular to what extent the systemic or generalised deficiencies so far as concerns the independence of the issuing Member State's judiciary are liable to have an impact at the level of that Member State's courts with jurisdiction over the proceedings to which that person will be subject" ${ }^{\prime 101}$. The assessment therefore also "involves taking into consideration the impact of such deficiencies which may have arisen after the issue of the [EAW] concerned" ${ }^{\text {"102 }}$, and not only the deficiencies existing at the time for issuing of the EAW.

This is also the case when an EAW is issued for the purposes of executing a custodial sentence or detention order, as in $P$, when the requested person "following his or her possible surrender, he or she will be subject to new court proceedings, on account of the bringing of an action

\footnotetext{
94 ibid, para 59.

95 ibid.

${ }^{96}$ ibid, para 60, italics added.

${ }^{97}$ ibid.

98 ibid, para 62.

99 ibid, paras 62-64.

100 ibid, para 65.

$101 \mathrm{ibid}$, para 66.

102 ibid, italics added.
} 
relating to the execution of that custodial sentence or that detention order or of an appeal against the judicial decision the execution of which is the subject of that [EAW], as the case may be" ${ }^{" 103}$. In this second situation, the executing judicial authority "must also examine to what extent the systemic or generalised deficiencies which existed in the issuing Member State at the time of issue of the [EAW] have, in the particular circumstances of the case, affected the independence of the court of that Member State which imposed the custodial sentence or detention order the execution of which is the subject of that [EAW]"104. In other words, when executing an EAW for the purposes of custodial sentence or detention order, the independence of the issuing authority, as well as the competent court of the eventual new court proceedings, has to be examined, but also the court of the original judgment which forms the basis for the EAW has to be assessed if that judgment was issued at a time when the systemic or generalised deficiencies in the issuing country already existed.

\section{ANALYSIS OF THE CASE}

\subsection{CONSTITUTIONAL PERSPECTIVE: UPHOLDING THE LM-PRECEDENT}

The Court's judgment in the joined cases $L$ and $P$ sends a clear message that a circumvention of the $L M$-established two-pronged test, constituting an exception from the Member States' main rule to execute an EAW, is not an option. A thorough examination of each step must be executed, regardless of how depraved the respect for the rule of law in the issuing Member State may be. The political stalemate within the Article 7 procedure, a situation which by now is clearly demonstrated ${ }^{105}$, does not either have any effect on the earlier case-law.

According to the rationale of the AG and the ECJ, the question is not how 'bad' the situation concerning the independence of judiciary of the issuing country may be, but rather the nature of the body which adopts a decision that in practice would result in a "de facto suspension of the (EAW) mechanism" 106 for the actual Member State. ${ }^{107}$ The justification of the Court's conclusion is Recital 10 of the FD EAW, stating that a decision pursuant to Article 7(2), and sanctions within Article 7(3), must have been adopted by the Council to enable the suspension of the cooperation mechanism. In the view of Pech, Wachowiec and Mazur, the logic in the Court's reasoning would in practice result in that albeit Poland would turn into a formal dictatorship, and no unanimously decision pursuant to Article 7 TEU is adopted by the Council, the national courts would still have to assess every EAW issued by Poland on a case-by-case basis. ${ }^{108}$

\footnotetext{
103 ibid, para 67, italics added.

104 ibid, para 68.

${ }^{105}$ Dimitry Kochenov, 'Article 7: A Commentary on a Much Talked-About 'Dead' Provision' in Armin von

Bogdandy et al (eds) Defending Checks and Balances in EU Member States: Taking Stock of Europe's Actions. (Springer, 2021), 127-154, 148.

106 Joined Cases C-354/20 and C-412/20 L and P EU:C:2020:1033, para 59.

107 ibid.; Opinion of Advocate General Campos Sánchez-Bordona delivered on 12 November 2020 in Joined Cases C-354/20 PPU and C-412/20 PPU L and P EU:C:2020:295, para 41.

108 Laurent Pech, Patryk Wachowiec and Dariusz Mazur, '1825 Days Later: The End of the Rule of Law in Poland (Part II)', (VerfBlog 18 January 2021) < https:/ /verfassungsblog.de/1825-days-later-the-end-of-the-ruleof-law-in-poland-part-ii/> accessed 19 May 2021.
} 
Similar reasoning was rendered by the Court in $L M$, which have been heavily criticised by prominent legal scholars. ${ }^{109}$ The critique has targeted inter alia the misconception of the FD EAW in relation to the 'new' Article 7(1) TEU ${ }^{110}$, and the fact that the ECJ gives secondary EU law precedence over primary law. ${ }^{111}$ Furthermore, the Court's high level of protection of the principles of mutual trust and recognition, prior to the maintenance of the rule of law, has been highly questioned. ${ }^{112}$ At the same time, opinions supporting the Court's reasoning in $L M$ have been expressed ${ }^{113}$, implicating inter alia that a solution in which an errant Member State had been excluded from the EAW mechanism would have been incompatible with the EU principles of conferral of powers, Article 5(1-2) TEU, and sincere cooperation, Article 4(3) TEU. ${ }^{114}$ This view may be legitimatised from a broader rule of lawperspective: the maintenance of the internal Union rule of law should not take place at the expense of the rule of law, which might be the case if the ECJ ruled against what is explicitly stated in the FD EAW and the fundamental principles of conferral and cooperation. Still, within the Common European Asylum System in the AFSJ, the ECJ has accepted nonstatutory exceptions from the main rule of transferring pursuant to 'Dublin' on account of either systematic deficiencies in the asylum system ${ }^{115}$, or due to personal circumstances in the individual case ${ }^{116}$. As noticed by Vandamme, the ECJ in the $L$ and $P$ judgment once more confirms the different treatment of international protection seekers vs. the surrender of suspected criminals in EU law, where in the latter category crime fighting seems to take precedence over fundamental rights concerns. ${ }^{117}$ At the same time, the Union objective to combat impunity is of substantial importance within the $\mathrm{AFSJ}^{118}$ and should not be overlooked. ${ }^{119}$

\footnotetext{
109 See e.g. Von Bogdandy et al. (n 105) 385-401; Stanisław Biernat and Paweł Filipek 'The Assessment of Judicial Independence Following the CJEU Ruling in C-216/18 LM' in Armin von Bogdandy et al (eds) Defending Checks and Balances in EU Member States: Taking Stock of Europe's Actions. (Springer, 2021) 403-430; Agnieszka Frąckowiak-Adamska, Agnieszka, 'Drawing Red Lines with No (Significant) Bites: Why an Individual Test Is Not Appropriate in the LM Case' in von Bogdandy (n 105) 443-454; Pech and Kochenov (n 25) 119-130; Wouter Van Ballegooij and Petra Bárd, 'The CJEU in the Celmer case: One step forward, two steps back for upholding the rule of law within the EU' (VerfBlog 29 July 2018)

$<$ https://verfassungsblog.de/the-cjeu-in-the-celmer-case-one-step-forward-two-steps-back-for-upholdingthe-rule-of-law-within-the-eu/> accessed 19 May 2021.

${ }^{110}$ Van Ballegooij and Bárd (n 109)

111 Pech and Kochenov (n 25) 127.

112 Van Ballegooij and Bárd (n 109).

113 See e.g. Konstadinides, 'Judicial independence and the Rule of Law in the context of non-execution of European Arrest Warrant: LM' (n 21) 764; Valsamis Mitsilegas (2019), 'The European Model of Judicial Cooperation in Criminal Matters: Towards Effectiveness Based on Earned Trust', Revista Brasileira de Direito Processual Penal, vol. 5, no. 2 (2019), 565-596, 584.

${ }^{114}$ See Theodore Konstadinides, 'Judicial independence and the Rule of Law in the context of non-execution of European Arrest Warrant: $L M$ ' (n 21) 764.

115 Joined Cases C-411/10 and C-493/10 NS EU:C:2011:865.

${ }_{116}$ Case C-578/16 PPU CK EU:C:2017:127.

117 See Thomas Vandamme 'The two-step can't be the quick step': The CJEU reaffirms its case law on the European Arrest Warrant and the rule of law backsliding', (European Law Blog 10 February 2021)

<https:/ / europeanlawblog.eu/2021/02/10/the-two-step-cant-be-the-quick-step-the-cjeu-reaffirms-its-caselaw-on-the-european-arrest-warrant-and-the-rule-of-law-backsliding/> accessed 19 May 2021.

118 Article 3(2) TEU and Article 67 TFEU.

119 Referred to in Opinion of Advocate General Campos Sánchez-Bordona delivered in Joined Cases C354/20 PPU and C-412/20 PPU L and P EU:C:2020:295, para 52 and in the Court's judgment, Joined Cases C-354/20 and C-412/20 L and P EU:C:2020:1033, paras 62-64.
} 
Anyhow, the fact that the Court did not extend the scope of its findings in the Prosecutors' Cases to also apply courts within the Union ought to be a sound deduction. Given the circumstance that it is not possible to separate the notion of 'judicial authority' within the EAW mechanism, and the general concept of 'court' in the EU law would result in the Polish courts being punished twice: the loss of their status as 'judicial authority' would also deny them the status of 'court' or 'tribunal' in the context of preliminary ruling procedures pursuant to Article 267. ${ }^{120}$ The Polish judges had thus been subject to severe threats against their independence at home and, at the same time, lost their opportunity to seek external support through the ECJ. ${ }^{121}$

\subsection{NATIONAL PERSPECTIVE: HORIZONTAL RULE OF LAW DIALOGUE}

Despite the above-mentioned approaches of the legal scholars concerning the Court's reasoning in $L M$ being diverse, most of them seem to have one thing in common: the practical enforcement of the two-step test concerning the judiciary's independence of the issuing country is complex and difficult for the national courts to navigate. ${ }^{122}$ The following analysis comments some key findings in the $L$ and $P$ case concerning the horizontal dialogue between the executing and issuing courts.

It is worth noting that the horizontal dialogue between the judicial authorities within the EAW mechanism is not in itself a new phenomenon. Article 15(2) of the FD EAW has since the establishment of the European system on extradition provided the executing judicial authority the opportunity to request supplementary information in the context of its decision on surrender. At an early stage within the AFSJ, the ECJ established in Advocaten voor de $W_{\text {ereld }}{ }^{123}$ the need for dialogue and submissions between the domestic courts in the context of the EAW mechanism. The Court subsequently left considerable room for the national authorities' discretion. ${ }^{124}$ However, what is new with the horizontal rule of law dialogue, originated in $L M$ and confirmed in $L$ and $P$, is that the conferred discretionary power now shall be applied within a complex assessment regarding the independence of the executing judicial authority's European counterpart. Contrary to Aranyosi and Căldăraru, which concerned shortcomings of the conditions in prisons, the issuing court in the situation at hand in $L M$ and $L$ and $P$ is required to answer questions about itself and the potential shortcomings of its own functions, not a separate branch within the administration of criminal justice. $^{125}$

\footnotetext{
${ }^{120}$ See e.g. Case C-54/94 Dorsch Consult EU:C:2008:461 concerning the concept of 'court' and 'tribunal' within EU law.

${ }^{121}$ See also Vandamme (n 117).

122 Pech and Kochenov (n 25) 126-129; Petra Bárd and John Morijn, 'Luxembourg's Unworkable Test to Protect the Rule of Law in the EU (Part I)' (VerfBlog, 18 April 2020)

$<$ https://verfassungsblog.de/luxembourgs-unworkable-test-to-protect-the-rule-of-law-in-the-eu/> accessed 19 May 2021; Konstadinides, 'Judicial independence and the Rule of Law in the context of non-execution of European Arrest Warrant: $L M$ ' (n 21) 767.

123 Case C-303/05 Advocaten voor de Wereld EU:C:2007:261.

${ }^{124}$ Daniel Sarmiento 'European Union: The European Arrest Warrant and the quest for constitutional coherence', International Journal of Constitutional Law, Vol. 6, Issue 1 (2008) 171-183, 171.

125 In the context of Joined Cases C-404/15 and C-659/15 PPU Aranyosi and Căldăraru EU:C:2016:198, the issuing Court shall answer questions about the correctional treatment system - a totally separate branch within the law enforcement system; Biernat and Filipek (n 109) 423.
} 
Moreover, the decentralisation of the examination of judicial independence to the national courts ought to result in a multitude of contradictory decisions. ${ }^{126}$ The aforementioned is not only alien to the general understanding of EU law, with the Court proclaiming uniform application of the Union legal sources ${ }^{127}$, but ought also to result in an erosion of the principle of mutual trust between the Member States, rather than strengthening the principle within the judicial cooperation. ${ }^{128}$ Following the Court's judgment in $L M$ in 2018, several domestic courts have applied the two-pronged test with varying result. ${ }^{129}$ In general, the questions hitherto asked by the executing authorities vary significantly regarding the substance and the level of detail between different countries, as well as different courts. ${ }^{130}$ Furthermore, Filipek and Biernat found that the answers from the Polish courts implies that they are only to a limited extent willing to cooperate in the context of the dialogue. ${ }^{131}$ Most answers merely include a brief presentation of general rules of the Polish judiciary, such as excerpts from the Polish constitution or extracts from public data. Occasionally, the answers contain vague ascertainments like "[i]n Poland, legal norms exclude threats to the independence of judges" ${ }^{\prime 32}$. According to Filipek and Biernat, only a few Polish courts, or rather judges, have expressed critical opinions vis-à-vis its independence from the executive. In this regard, the information has primarily concerned previous disciplinary procedures against judges. The strong influence from the Minister of Justice regarding the court's administration, as well as arbitrary appointments or dismissals of Presidents of the Courts, have also been reported. ${ }^{133}$ Additionally, the horizontal dialogue has resulted in disputes between the Member States: the District Court in Warsaw, as an immediate response on the Dutch reference for a preliminary ruling in $L$ and $P$, denied the execution of a Dutch EAW on account of, pursuant to the Warsaw court, inter alia the politician interference in judicial appointments in the Netherlands. ${ }^{134}$

As noted by the Court of Justice, as well as the Advocate General, in the light of increased systemic or generalised deficiencies in the issuing Member State, the executing authority has to "exercise vigilance" 135 throughout an "even more rigorous examination"136 of the issuing authority. However, the exact procedure for the horizontal dialogue remains,

\footnotetext{
126 Pech and Kochenov (n 25) 131.

127 Jörgen Hettne and Ida Otken Eriksson EU-rättslig metod: teori och genomslag i svensk rättstillämpning (Norstedts Juridik: 2011), 21-22.

128 Pech and Kochenov (n 25) 131.

${ }^{129}$ Petra Bárd and John Morijn, 'Domestic Courts Pushing for a Workable Test to Protect the Rule of Law in the EU (Part II)' (VerfBlog 19 April 2020): < https://verfassungsblog.de/domestic-courts-pushing-for-aworkable-test-to-protect-the-rule-of-law-in-the-eu/> accessed 19 May 2021; Biernat and Filipek (n 109) 421. 130 See e.g. Decision of 10 Februari 2021 by Rechbank Amsterdam, ECLI:NL:RBAMS:2021420; Decision of 31 October 2021 by Oberlandesgericht Karlsruhe, Ausl 301 AR 95/18.

131 Biernat and Filipek (n 109) 421.

132 ibid.; Regional Court in Warsaw (Letter of 26 September 2018)

<http://bip.warszawa.so.gov.pl/attachments/download/7511> accessed 19 May 2021.

133 Biernat and Filipek (n 109) 421-422.

${ }^{134}$ Ruleoflaw.pl 'District Court in Warsaw judge accuses a Dutch court of obstruction in the European Arrest Warrant cases < https://ruleoflaw.pl/district-court-in-warsaw-european-arrest-warrant/> accessed 19 May 2021; Reuters 'Polish deputy minister questions independence of Dutch judges'

<https://www.reuters.com/article/uk-poland-netherlands-extradition-idUKKCN26C2TX> accessed 19 May 2021.

135 Joined Cases C-354/20 and C-412/20 L and P EU:C:2020:1033, para 60.

136 Opinion of Advocate General Campos Sánchez-Bordona delivered in Joined Cases C-354/20 PPU and C412/20 PPU L and P EU:C:2020:295, para 76.
} 
as noted above, open for the issuing court to decide. Some comments on the different steps are presented below.

\section{2[a] The Factual Background of the Dispute}

The concrete risk for a breach of the requested person's right to a fair trial, in the context of the examination within the second, individual, step is the part of the national assessment which has been subject for the majority of the critique against the horizontal rule of law dialogue established in $L M$. As put by Biernat and Filipek, the entire test may be complex but the degree of complexity increases by each step of the examination. ${ }^{137}$ The scrutiny of the systemic or generalised deficiencies may indeed be problematic for the executing authority to prove in a situation where no comprehensive and/or up-to-date documents are available from objective parties concerning the systemic dismantling of the rule of law in the actual country. ${ }^{138}$ However, this is not the case in the situation at hand regarding the Polish judiciary. Within the current situation, there are multiple reports from the Commission, as well as the Venice Commission, and significant case-law from the CJEU supporting the examination within the first step. The systemic or generalised deficiencies shall be determined upon "objective, reliable, specific and properly updated material indicating that there is a real risk of breach of the fundamental right to a fair trial guaranteed by the second paragraph of Article 47 of the Charter". ${ }^{139}$ The reasoned proposal of the Commission adopted pursuant to Article 7(1) TEU is identified as an appropriate example of such material. ${ }^{140}$ The material ought to originate from an objective third party, such as the Commission, the Council of Europe, the CJEU or the ECHR. In the context of the first step, the intention from the ECJ ought not to be that the executing court asks questions about the general situation in the issuing country. Thus, the horizontal dialogue should focus on the second step presented below. ${ }^{141}$

Regardless of how severe the systemic or generalised deficiencies concerning the independence of the judiciary in the issuing Member State may be, the Court has explicitly emphasised that it is not possible for the executing authority to presume that these deficiencies result in a concrete risk in the individual case at hand. ${ }^{142}$ The potential deterioration of the deficiencies can only result in the executing authority having to "exercise vigilance" 143 within its examination. A thorough examination pursuant to the second step is consequently obligatory for the executing authority, thus avoiding breaching the Union law laid down by the Court. ${ }^{144}$

\footnotetext{
137 Biernat and Filipek (n 109) 415.

138 ibid, 403-430, 415-17; Konstadinides, 'Judicial independence and the Rule of Law in the context of nonexecution of European Arrest Warrant: $L M^{\prime}$ ' (n 21) 752.

${ }^{139}$ Case C-216/18 PPU LM EU:C:2018:586, para 61; Joined Cases C-354/20 and C-412/20 L and P

EU:C:2020:1033, para 54.

${ }^{140}$ Joined Cases C-354/20 and C-412/20 L and P EU:C:2020:1033, para 52.

${ }^{141}$ Case C-216/18 PPU LM EU:C:2018:586, para 76; Joined Cases C-354/20 and C-412/20 L and P

EU:C:2020:1033 para 61.

142 Joined Cases C-354/20 and C-412/20 L and P EU:C:2020:1033 para 59.

143 ibid, para 60.

144 ibid; Håkan Friman, Ulf Wallentheim and Joakim Zetterstedt Överlämnande enligt en europeisk eller nordisk arresteringsorder - en kommentar (Wolters Kluwer, 2016), 40-41.
} 


\section{2[b] The Individual Assessment}

The second step within the rule of law-test actually contains two different examinations within the individual situation for the requested person. ${ }^{145}$ Firstly, the executing authority must determine to what extent the above-mentioned systemic and generalised deficiencies, found within the first step, affect the courts which have jurisdiction over the proceedings that the requested individual might be subject for. ${ }^{146}$ Secondly, the executing authority shall assess the situation in relation to the specific case and the individual person being prosecuted. It is not until the last ultimate test has been answered, i.e. whether there is a real risk of a breach of the fundamental right to a fair trial of the person subject of the EAW, that the executing authority can refuse to execute the EAW at hand. ${ }^{147} \mathrm{~A}$ vital issue for the executing authority to take into consideration in the context of the individual assessment is specifically who in the issuing country should answer the questions within the horizontal dialogue. The Court's reasoning does not in neither $L M$ nor $L$ and $P$ clarify if the additional information should be communicated by e.g. the judge issuing the EAW, or the President of the issuing court in general. In practice, questions from a foreign court are normally answered by either the President of the Court or the manager of the department for international cooperation. ${ }^{148}$ On request from the executing authority it occurs that individual judges reply. When the information originates from the President or the responsible manager, the answers tend to be brief and/or generic. Consequently, there is limited usage for the information within the executing authority's decision of surrender. Contrary to when the answers originate from an individual judge issuing the EAW, the information tend to be comprehensive and straightforward. ${ }^{149}$

The intermediate stage concerning the forthcoming competent courts, which did not exist in the Aranyosi \& Căldăraru case, is legitimised by the subject-matter which differ from the examination of e.g. conditions in prisons. ${ }^{150}$ In the context of the scrutiny of the competent courts, the executing authority must first identify the courts in the issuing Member State which have jurisdiction to rule on the matters in question. This will either require that the executing authority applies the rules of criminal procedure of that state, or through asking questions to the issuing authority within the horizontal dialogue pursuant to Article 15(2) of the FD EAW. ${ }^{151}$ The latter was implemented by the Rechtbank Amsterdam in the national procedures in both $L$ and $P .{ }^{152}$ Following the identification of the competent courts, the executing authority must determine if, and if so, to what extent these courts independence are subject to jeopardy from the executive. The risks shall be interconnected with the systemic or generalised deficiencies in the issuing country's judiciary. To determine the aforementioned, there is no predetermined 'check-list' for the executing court to 'tick off, but instead the assessment differ from case-to-case. The questions asked by Rechtbank

\footnotetext{
145 See also Biernat and Filipek (n 109) 403-430, which divided the examination into three different steps. ${ }^{146}$ Case C-216/18 PPU LM EU:C:2018:586, para 74; Joined Cases C-354/20 and C-412/20 L and P EU:C:2020:1033, para 66.

147 Biernat and Filipek (n 109) 413-414.

148 ibid, 424-425.

149 ibid.

150 ibid, 413-414.

151 ibid, 416-417.

152 Request for a preliminary ruling in Case C-354-20 PPU L, para 9.
} 
Amsterdam may illustrate some concerns that can be depicted. The Dutch court asked questions concerning changes in staffing, allocation and handling of cases, disciplinary cases or other measures and procedures to protect the right to an independent tribunal and on the 'extraordinary appeal.' ${ }^{153}$

Concerning the relevant time for when the systemic or generalised deficiencies stated in the first step emerged, the most important findings confirmed in $L$ and $P$ regard two main cases: (1) a review of the competent courts for the coming criminal procedure, thus relevant in both the surrender of an EAW for conduction of a criminal prosecution, and for the execution of a custodial sentence if the original judgment is to be reviewed in a new court procedure, and; (2) when executing an EAW on the grounds of the execution of a custodial sentence, the executing authority might need to examine the independence of the court that convicted the original sentence if that judgment was passed when the systemic or generalised deficiencies already existed. ${ }^{154}$

Following the determination of (1) systemic or generalised deficiencies concerning the independence of the judiciary of the issuing Member State, and (2) that these deficiencies affect the courts which have jurisdiction over the proceedings that the requested individual might be subject to, it is time for the ultimate question: whether there is a real risk of a breach of the fundamental right to a fair trial of the person subject of the EAW. Within this last assessment, the executing judicial authority must "assess specifically and precisely whether in the particular circumstances of the case there are substantial grounds for believing that following that surrender [the requested person] will run a real risk of breach of his or her fundamental right to a fair trial"155. The examination shall be conducted with regard to "his or her personal situation, to the nature of the offence for which he or she is being prosecuted and the factual context in which that arrest warrant was issued, and in the light of any information provided by that Member State pursuant to Article 15(2) of the [FD EAW], there are substantial grounds for believing that that person will run such a risk if he or she is surrendered to that Member State" ${ }^{\prime 156}$.

Whether there is a substantial ground for believing that following the surrender, there is a real and concrete risk for a breach of a fundamental right of the requested person is probably more feasible in a situation when the executing judicial authority is to examine a specific detention center. Thus, when the assessment is addressed to the overall judicial situation for the requested person it might not be near as practicable as in the Aranyosi \& Căldăraru situation. ${ }^{157}$ Thus, the logic in the two-pronged fundamental rights test, with high requirements on concrete evidence, ought to be a better method in the examination of concrete situations.

\section{CONCLUDING REMARKS}

In the $L$ and $P$ ruling, the Court of Justice establish that a national court always possesses the status of 'issuing judicial authority' in the context of the EAW mechanism; a conclusion

153 ibid.

${ }^{154}$ Joined Cases C-354/20 and C-412/20 L and P EU:C:2020:1033, paras 65-69.

155 ibid, para 66.

156 ibid, para 55, italics added.

157 Von Bogdandy et al. (2021) 'A Potential Constitutional Moment for the European Rule of Law: The Importance of Red Lines', in von Bogdandy et al. (n 105) 398-400. 
which, in the view of the current case-law within the notion of 'court' in the general Union law (e.g. the possibility of reference for a preliminary ruling pursuant to Article 267 TFEU), is fairly reasonable. However, the position of the ECJ - "[i]n European Union law, the requirement that courts be independent precludes the possibility that they may be subject to a hierarchical constraint or subordinated to any other body and that they may take orders or instructions from any source whatsoever" ${ }^{\prime 158}$ - may need some altering. This ideal of courts being inherently independent within the Member States does not reflect the current reality in the Union.

Furthermore, the joined cases in $L$ and $P$ firmly solidifies the ECJ's earlier case-law in $L M$ concerning the two-step rule of law-test, which constitutes a possibility of refusal to surrender a requested person by an EAW. Henceforth, the two-step scrutiny shall be conducted by the executing judicial authority within a horizontal dialogue including multiple complex questions, such as whether its European counterpart is independent or not. Thus, a heavy burden is placed on the national executing court, and judges, as well as the issuing court and the judges answering the questions. In this regard, the plausible chilling effect in the Polish judiciary due to e.g. the current reforms and ongoing disciplinary procedures against Polish judges, cannot be overlooked. ${ }^{159}$

There are many indications that the Court's requirement on the executing court to state a real risk of a breach on the requested person's fundamental right to a fair trial, assessed on a case-by case-basis, is an inappropriate tool to tackle the rule of law-crisis in Poland. Since the Polish reforms hollow out the independence of the judiciary as a whole, there is no point in conducting an individual and specific assessment; within the current Polish situation, there is always a real risk of a person being subject for a court process which, in one way or another, is affected by the executive. Even though the individual judge in the specific case might not have been directly interfered by the executive, the chilling effect stemming from the imminent risk of external interference ought to entail that the adjudication cannot be perceived as independent. ${ }^{160}$

It remains to be seen whether the rule of law-scrutiny between the national courts will in practice result in an increased respect for the rule of law within the Member States. Unfortunately, there are many indications that the two-pronged test is nearly impossible to execute in reality. By contrast, something positive with the ECJ's rulings in $L M$ and $L$ and $P$ is that the EU rule of law-crisis no longer is an issue only for the Council, Commission and CJEU to deal with it. The common respect for the rule of law is nowadays a question for all European courts, including the national, to monitor and uphold.

\footnotetext{
158 Joined Cases C-354/20 and C-412/20 L and P EU:C:2020:1033, para 49.

159 See e.g. Biernat and Filipek (n 109) 410.

160 ibid.
} 


\section{LIST OF REFERENCES}

Bradford A, 'The Brussels Effect' (2012) Northwestern University Law Review 107(1), 1 -67, available at: https://scholarship.law.columbia.edu/faculty scholarship/271

Bárd P, Morijn J, 'Luxembourg's Unworkable Test to Protect the Rule of Law in the EU (Part I)' (VerfBlog, 18 April 2020) available at: < https://verfassungsblog.de/luxembourgsunworkable-test-to-protect-the-rule-of-law-in-the-eu/> (accessed 19 May 2021)

Bárd P, Morijn J, 'Domestic Courts Pushing for a Workable Test to Protect the Rule of Law in the EU (Part II)' (VerfBlog 19 April 2020) available at: $<$ https:/ / verfassungsblog.de/domestic-courts-pushing-for-a-workable-test-to-protect-therule-of-law-in-the-eu/> (accessed 19 May 2021)

Biernat S, Filipek P, 'The Assessment of Judicial Independence Following the CJEU Ruling in C-216/18 LM' in Armin von Bogdandy et al (eds.) Defending Checks and Balances in EU Member States: Taking Stock of Europe's Actions. (Springer, 2021) 403-430 DOI: https://doi.org/10.1007/978-3-662-62317-6_16

Böse M, 'The European arrest warrant and the independence of public prosecutors: $O G \&$ PI, PF, JF \& YC, Common Market Law Review, No. 57 (2020)

Craig P, de Búrca G, EU Law; Text, Cases and Materials (Oxford University Press, 2020)

Euronews 'Hundreds of judges and lawyers protest against Polish 'muzzle-law' (11 January 2020) available at: <https://www.euronews.com/2020/01/11/hundreds-of-judges-andlawyers-join-warsaw-protest-against-polish-muzzle-law $>$ (accessed 19 May 2021)

Euronews 'Germany refuses to extradite Pole under European arrest warrant due to fair trial fears’ (10 March 2020) available at: < https://www.euronews.com/2020/03/09/germanyrefuses-to-extradite-pole-under-european-arrest-warrant-due-to-fair-trial-fears $>$ (accessed 19 May 2021)

European Commission, Report from the Commission on the implementation since 2005 of the Council Framework Decision of 13 June 2002 on the European arrest warrant and the surrender procedures between Member States, $\operatorname{COM}(2007) 407$ final

European Commission, Reasoned proposal in accordance with Article 7.1 of the Treaty on European Union regarding the rule of law in Poland: Proposal for a Council decision on the determination of a clear risk of a serious breach by the Republic of Poland of the rule of law, $\operatorname{COM}(2017) 835$ final

European Commission, Communication from the Commission to the European Parliament and the Council on A new EU Framework to strengthen the Rule of Law, COM(2014) 158 final 
European Commission, Communication from the Commission to the European Parliament, the Council, the European Economic and Social Committee and the Committee of the Regions on 2020 Rule of Law Report, $\operatorname{COM}(2020) 580$ final

European Commission, Commission Staff Working Document, 2020 Rule of Law Report, Country Chapter on the rule of law situation in Poland (SWD(2020) 320 final

European Parliament, Proposal for a Council decision on the determination of a clear risk of a serious breach by the Republic of Hungary of the rule of law, 2018/0902(NLE)

Frąckowiak-Adamska A, Agnieszka, 'Drawing Red Lines with No (Significant) Bites: Why an Individual Test Is Not Appropriate in the LM Case' in Armin von Bogdandy et al (eds.) Defending Checks and Balances in EU Member States: Taking Stock of Europe's Actions. (Springer, 2021), 443-454

DOI: https://doi.org/10.1007/978-3-662-62317-6_18

Freedom House 'Poland: Restrictive Judiciary Law Sets Dangerous Precedent' (23 January 2020) available at: $<$ https://freedomhouse.org/article/poland-restrictive-judiciary-law-setsdangerous-precedent $>$ (accessed 19 May 2021)

Friman H, Wallentheim U, Zetterstedt J, Överlämnande enligt en europeisk eller nordisk arresteringsorder - en kommentar (Wolters Kluwer, 2016)

Gill-Pedro E, Groussot X, 'The Duty of Mutual Trust in EU Law and the Duty to Secure Human Rights: Can the EU's Accession to the ECHR Ease the Tension?', Nordic Journal of Human Rights, 35:3 (2017), 258-274

DOI: https://doi.org/10.1080/18918131.2017.1355477

Groussot X, Lindholm J, 'General Principles: Taking Rights Seriously and Waving the Ruleof-Law Stick in the European Union' in Constructing Legal Orders in Europe: General Principles of EU Law (Edward Elgar Publishing, 2019)

DOI: http://dx.doi.org/10.2139/ssrn.3361668

Herlin-Karnell E, 'Ett konstitutionellt perspektiv på frågan om tillit inom EU:s straffrättsliga samarbete' in A. Bakardjieva Engelbrekt et al (eds.) Tilliten i EU i ett vägskäl (Santérus förlag, 2017) 161-184

Hettne J, Otken Eriksson I, EU-rättslig metod: teori och genomslag $i$ svensk rättstillämpning (Norstedts Juridik: 2011)

Klimek L, European Arrest W arrant (Springer International Publishing, 2015)

Klimek L, Mutual Recognition of Judicial Decisions in European Criminal Law (Springer International Publishing, 2017) 
Kochenov D, 'Article 7: A Commentary on a Much Talked-About 'Dead' Provision' in Armin von Bogdandy et al (eds) Defending Checks and Balances in EU Member States: Taking Stock of Europe's Actions. (Springer, 2021)

DOI: https://doi.org/10.1007/978-3-662-62317-6_6

Konstadinides T, 'The Europeanisation of extradition: how many light years away to mutual confidence?', in C. Eckes (eds.), Crime within the Area of Freedom, Security and Justice (Cambridge University Press, 2011) 192-223

DOI: https://doi.org/10.1017/CBO9780511751219.008

Konstadinides T, The Rule of Law in the European Union: The Internal Dimension (Hart Publishing, 2017)

Konstadinides T, 'Judicial independence and the Rule of Law in the context of non-execution of European Arrest Warrant: LM', Common Market Law Review, Vol. 56 (2019) 743-770

Lenaerts K, 'La vie après l'Avis: Exploring the principle of mutual (yet not blind) trust', Common Market Law Review, Vol. 54 (2017) 805-840

Mitsilegas V, (2019), 'The European Model of Judicial Cooperation in Criminal Matters: Towards Effectiveness Based on Earned Trust', Revista Brasileira de Direito Processual Penal, vol. 5, no. 2 (2019), 565-596

DOI: https://doi.org/10.22197/rbdpp.v5i2.248

Pech L, Kochenov D, 'Respect for the Rule of Law of the European Court of Justice: A Casebook Overview of Key Judgments since the Portugese Judges Case', SIEPS Report (Stockholm, 2021 forthcoming)

Pech L, Wojciech S, Lane Scheppele K, 'Open Letter to the President of the European Commission regarding Poland's "Muzzle Law" (Verfblog 9 March 2020) available at: $<$ https://verfassungsblog.de/open-letter-to-the-president-of-the-european-commissionregarding-polands-muzzle-law/> (accessed 19 May 2021)

Pech L, Wachowiec P, Mazur D, '1825 Days Later: The End of the Rule of Law in Poland (Part II)', (VerfBlog 18 January 2021) available at: < $\underline{\text { https://verfassungsblog.de/1825-days- }}$ later-the-end-of-the-rule-of-law-in-poland-part-ii/ $>$ ( accessed 19 May 2021)

Reuters 'Polish deputy minister questions independence of Dutch judges' (21 September 2020) available at <https://www.reuters.com/article/uk-poland-netherlands-extraditionidUKKCN26C2TX> (accessed 19 May 2021)

Ruleoflaw.pl 'District Court in Warsaw judge accuses a Dutch court of obstruction in the European Arrest Warrant cases (29 September 2020) available at: $<$ https://ruleoflaw.pl/district-court-in-warsaw-european-arrest-warrant/> (accessed 19 May 2021) 
Sarmiento D, 'European Union: The European Arrest Warrant and the quest for constitutional coherence', International Journal of Constitutional Law, Vol. 6, Issue 1 (2008) 171-183

DOI: https://doi.org/10.1093/icon/mom040

Themis newsletter 'Close to the point of no return (newsletter about the situation of the Polish judiciary)' (20 February 2020) available at: < $\underline{\text { http://themis-sedziowie.eu/wp- }}$ content/uploads/2020/02/Newsletter.pdf> (accessed 19 May 2021)

TVn24 'A Spanish court is questioning independence of Polish Judicial System' (3 October 2018) available at: <https://tvn24.pl/tvn24-news-in-english/a-spanish-court-isquestioning-independence-of-polish-judicial-system-ra873141-2582920> (accessed 19 May 2021)

Van Ballegooij W, Bárd P, 'The CJEU in the Celmer case: One step forward, two steps back for upholding the rule of law within the EU' (VerfBlog 29 July 2018) available at: $<\underline{\text { https://verfassungsblog.de/the-cjeu-in-the-celmer-case-one-step-forward-two-steps- }}$ back-for-upholding-the-rule-of-law-within-the-eu/> (accessed 19 May 2021)

Vandamme T, 'The two-step can't be the quick step': The CJEU reaffirms its case law on the European Arrest Warrant and the rule of law backsliding', (European Law Blog 10 February 2021) available at: < https://europeanlawblog.eu/2021/02/10/the-two-step-cant-be-thequick-step-the-cjeu-reaffirms-its-case-law-on-the-european-arrest-warrant-and-the-rule-oflaw-backsliding/> (accessed 19 May 2021)

Von Bogdandy A, et al. (2021) 'A Potential Constitutional Moment for the European Rule of Law: The Importance of Red Lines', in Armin von Bogdandy et al. (eds.), Defending Checks and Balances in EU Member States: Taking Stock of Europe's Actions (Springer, 2021), 385-401 